CZASOPISMO INŻYNIERII LĄDOWEJ, ŚRODOWISKA I ARCHITEKTURY JOURNAL OF CIVIL ENGINEERING, ENVIRONMENT AND ARCHITECTURE

JCEEA, t. XXXIV, z. 64 (4//I/17), październik-grudzień 2017, s. 363-378, DOI:10.7862/rb.2017.220

\author{
Agnieszka WDOWIAK ${ }^{1}$
}

\title{
STRUKTURA DREWNA KONSTRUKCYJNEGO
}

\begin{abstract}
Drewno to priorytetowy surowiec dla przemysłu celulozowego i energetycznego. Źródłem surowcowym są lasy. Powierzchnia lasów w Polsce, z roku na rok, nieustannie wzrasta. Wzrost lesistości od roku 1945 wynosi 8,4\%. Przyrost ten jest wynikiem zalesiania gruntów użytkowanych przez rolnictwo i nieużytków [1].

W monografii przedstawiono budowę mikroskopową i makroskopową drewna sosny zwyczajnej Pinus sylvestris L., pochodzącej z czterech wybranych krain przyrodniczoleśnych Polski: Kraina A - Mazowiecko - Podlaska Kraina Przyrodniczo - Leśna (Nadleśnictwo Garwolin), Kraina B - Małopolska Kraina Przyrodniczo - Leśna (Nadleśnictwo Przedbórz), Kraina C - Śląska Kraina Przyrodniczo - Leśna (Nadleśnictwo Kędzierzyn Koźle), Kraina D - Karpacka Kraina Przyrodniczo - Leśna (Nadleśnictwo Piwniczna). Ukazano strukturę mikroskopową jodły pospolitej Abies alba Mill, modrzewia europejskiego Larix decidua Mill. pochodzącego z zabytkowego obiektu wybudowanego w 1860 r., sosny zwyczajnej Pinus sylvestris L. poddanej 5 - letnim wpływom atmosferycznym oraz degradacji biologicznej.

Określono przyrosty roczne, biel i twardziel, pęcherze i wycieki żywiczne oraz promienie łykodrzewne. Zaprezentowano właściwości rozpoznawcze wybranych rodzajów drewna iglastego, w szczególności zabarwienie twardzieli, szerokość przyrostów rocznych, udział bielu i twardzieli, obecność przewodów żywicznych, przejście z drewna wczesnego do późnego czy strukturę sęka.

Dodatkowo scharakteryzowano takie gatunki drzew, jak sosna zwyczajna Pinus sylvestris L., świerk pospolity Picea abies Karst., modrzew europejski Larix decidua Mill., jodła pospolita Abies alba Mill., daglezja zielona Pseudotsuga menziesii Franco [1-2].

Słowa kluczowe: drewno, struktura mikroskopowa, struktura makroskopowa, przyrosty roczne, biel i twardziel, pęcherze i wycieki żywiczne, promienie łykodrzewne, sosna zwyczajna Pinus sylvestris L., świerk pospolity Picea abies Karst., modrzew europejski Larix decidua Mill., jodła pospolita Abies alba Mill., daglezja zielona Pseudotsuga menziesii Franco
\end{abstract}

\section{Wprowadzenie}

Drewno jest nieustannie używane i ma tysiące zastosowań praktycznych, pomimo swoich wad jak i zalet. Postać proekologiczna, recyklingowa oraz estetyczna, spowodowana jest satysfakcjonującą charakterystyką fizykomechaniczną tego surowca organicznego. Pomyślne właściwości mechaniczne, cieplne, aku-

${ }^{1}$ Agnieszka Wdowiak, Politechnika Świętokrzyska, Wydział Budownictwa i Architektury, Katedra Inżynierii Komunikacyjnej, Zakład Remontów i Utrzymania Budowli, al. Tysiąclecia Państwa Polskiego 7, 25-314 Kielce, tel. 413424 444, 3424 445, awdowiak@tu.kielce.pl 
styczne są podstawą wznoszenia nowoczesnego budownictwa szkieletowego. Szeroko stosowane drewno we wnętrzach mieszkalnych jest wynikiem podnoszenia poziomu wyposażenia, komfortu jak również zdrowotności [1].

Drewno jest materiałem, który ukazuje, w odniesieniu do rodzaju, wielką nierównomierność swoich własności. To materiał anizotropowy - zróżnicowane cechy w różnych kierunkach i niejednorodny - wady [3-6].

Budynki drewniane były realizowane w różnych latach, nie mniej jednak pewna ich część pochodzi nawet z końca XIX w. Tworzą one część zabudowy wsi, małych miasteczek i peryferii większych miast. Zazwyczaj to budynki parterowe bądź jednopiętrowe, czasem dwupiętrowe. Większa ich część, nie jest podpiwniczona a mniejsza - cząstkowo podpiwniczona. Wśród budynków mieszkalnych o konstrukcji drewnianej, w większości budowano na Podkarpaciu. Realizowano je w stylu zakopiańskim. Inne obszary odznaczały się przede wszystkim budynkami tymczasowymi, niekiedy rolniczymi, obiektami rekreacyjnymi, altankami w ogródkach działkowych. Współcześnie mieszkalne budynki drewniane wykonywane są zazwyczaj w formie lekkiego szkieletu (system kanadyjski). Nadal buduje się je w konstrukcji odnoszącej się do tradycyjnej - z bali $[4,6]$.

$\mathrm{W}$ ostatnim okresie rośnie popyt na tarcicę konstrukcyjną. Ich rola w budownictwie jest coraz to większa, w wyniku nowoczesnej technologii zabezpieczania oraz produkcji. W naszym kraju tarcica konstrukcyjna jest wykorzystywana do produkcji tradycyjnych i prefabrykowanych więźb dachowych a także do wznoszenia ścian domów o konstrukcji szkieletowej. Sukcesywnie rośnie również produkcja elementów konstrukcyjnych klejonych warstwowo z tarcicy [7-8].

\section{Struktura drewna}

\subsection{Struktura mikroskopowa drewna}

Do budowy mikroskopowej drewna przyporządkowuje się elementy budowy, dostrzegalne przy użyciu mikroskopu optycznego. Innymi słowy, podmioty o zakresie mniejszym niż $0,1 \mathrm{~mm}$ i większym niż połowa rozciągłości fali świetlnej. Podmiotami są komórki formujące strukturę drewna. Dlatego też, inna jest budowa drewna iglastego, a inna liściastego - budują ją komórki różnego typu [1,9].

Drewno zestawione jest z komórek. Struktura komórek roślinnych uzależniona jest od ich funkcji, warunków otoczenia (wzrostu) oraz członkowstwa rośliny w danej grupie systematycznej. W drewnie wyodrębnia się dużą ilość grup komórek [3].

Drewno drzew iglastych posiada stosunkowo prostą budowę. Badania mikroskopowe przeprowadzono w laboratorium Katedry Wytrzymałości Materiałów, Konstrukcji Betonowych i Mostowych Politechniki Świętokrzyskiej z wykorzystaniem skaningowego mikroskopu elektronowego (SEM). Schematy budowy warstwowej ściany komórkowej przedstawiają rys. 1, 2, 3, 4, 5, 6, 7 i 8. Uzyskane obserwacje budowy mikroskopowej drewna świeżego sosny zwyczajnej Pinus sylvestris L. i jodły pospolitej Abies alba Mill. oraz drewna zabytkowego modrzewia europejskiego Larix decidua Mill., uściślają dotychczasowe dane dotyczące struktury. 


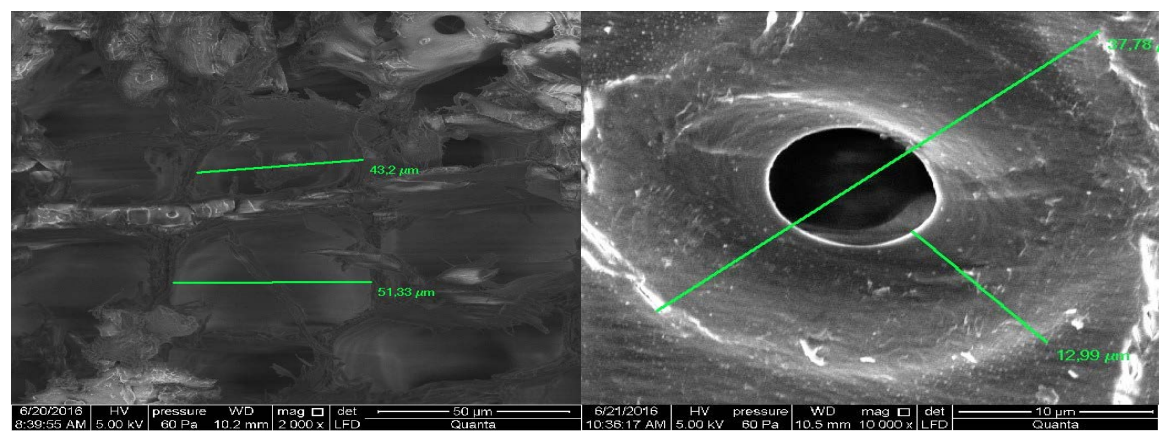

Rys. 1. Budowa mikroskopowa sosny zwyczajnej Pinus sylvestris L. pochodzącej z Nadleśnictwa Garwolin

Fig. 1. Microscopic structure of pine Pinus sylvestris L. from Garwolin Forest Inspectorate

Zasadniczym budulcem drewna (ksylemu) są cewki, formujące przewodnią część drewna iglastego. Pełnią funkcję wzmacniania i przewodzenia wody. Cewki u pierwotnych i lądowych roślin, posiadają pierścieniowe lub spiralne zgrubienia, znajdujące się na wewnętrznej powierzchni ścian. Definiują funkcję wzmacniania osiowych narządów rośliny. Cewki są to wydłużone, wchodzące na siebie, komórki martwe, o zdrewniałych ścianach, z częstymi jamkami lejkowatymi, jakimi woda dobiega $\mathrm{w}$ kierunku podłużnym i poprzecznym. Promienie łykodrzewne ciągną się prostopadle do cewek i są wytworzone głównie z komórek miękiszowych. U niektórych gatunków iglastych występują również cewki poziome. U sosny, świerka i modrzewia, dodatkiem są rzadkie komórki miękiszowe, budujące miękisz drzewny, pojawiający się jedynie w sąsiedztwie pionowych kanałów żywicznych. Kanały żywiczne rozchodzą się równolegle do osi pędu i zbiegają się w układ sieci, biegnący promieniście, w zespoleniu z poziomymi przewodami w złożonych promieniach łykodrzewnych [1-2].

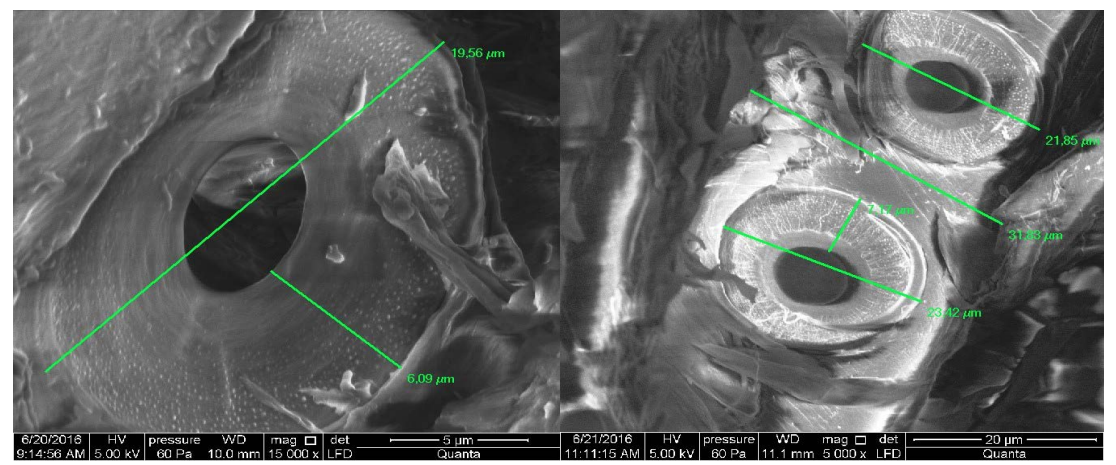

Rys. 2. Budowa mikroskopowa sosny zwyczajnej Pinus sylvestris L. pochodzącej z Nadleśnictwa Przedbórz

Fig. 2. Microscopic structure of pine Pinus sylvestris L. from Przedbórz Forest Inspectorate 


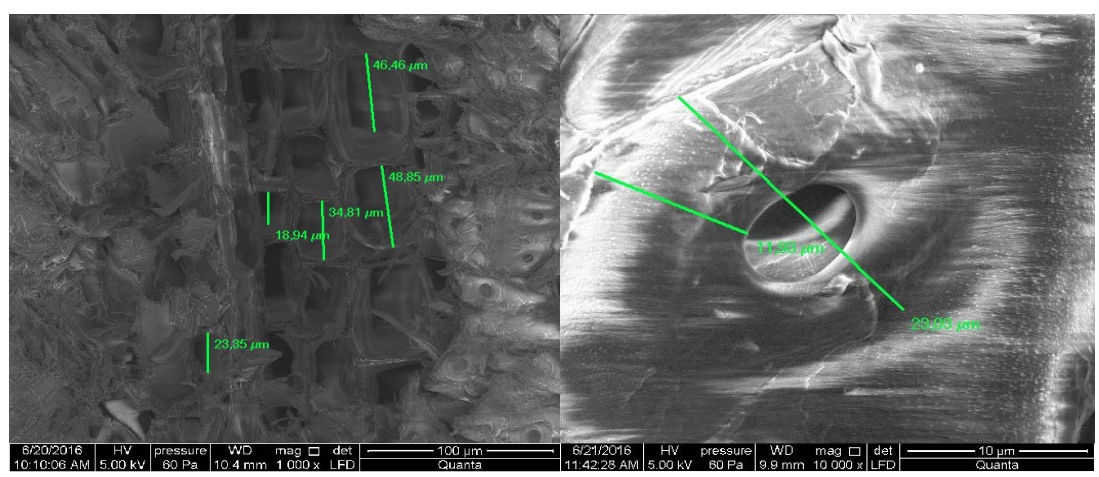

Rys. 3. Budowa mikroskopowa sosny zwyczajnej Pinus sylvestris L. pochodzącej z Nadleśnictwa Kędzierzyn Koźle

Fig. 3. Microscopic structure of pine Pinus sylvestris L. from Kędzierzyn Koźle Forest Inspectorate

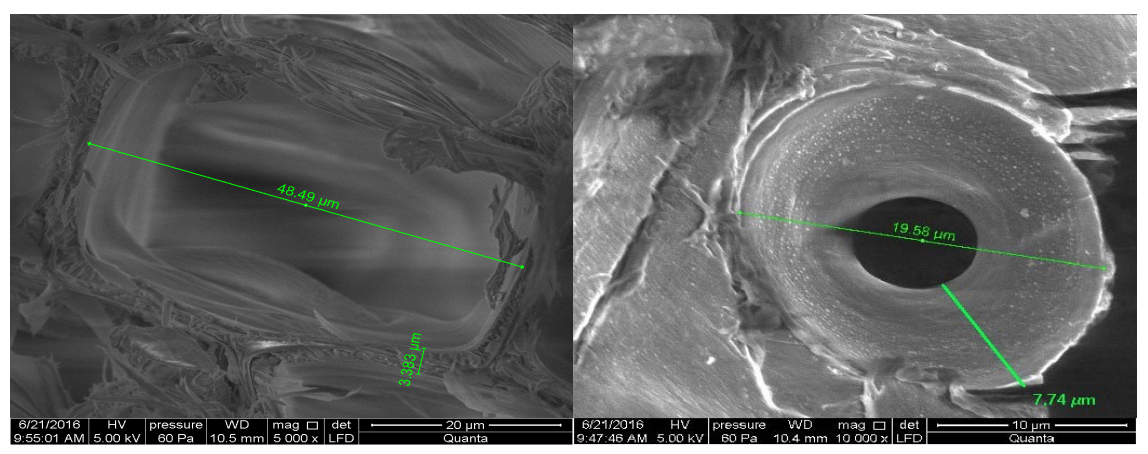

Rys. 4. Budowa mikroskopowa sosny zwyczajnej Pinus sylvestris L. pochodzącej z Nadleśnictwa Piwniczna

Fig. 4. Microscopic structure of pine Pinus sylvestris L. from Piwniczna Forest Inspectorate

Cewki w dwóch kierunkach, przewodzenia lub wzmacniania, ukierunkowały się etapowo. Usprawnianie przewodzenia kosztem sprawności wzmacniania, przyczyniło się do utworzenia naczyń. Pojawiające się u niemalże wszystkich roślin okrytonasiennych (drzew liściastych). Formy pierwotniejsze posiadają człony naczyń dłuższe i węższe a formy bardziej rozwinięte - krótsze i szersze [1-2]. 


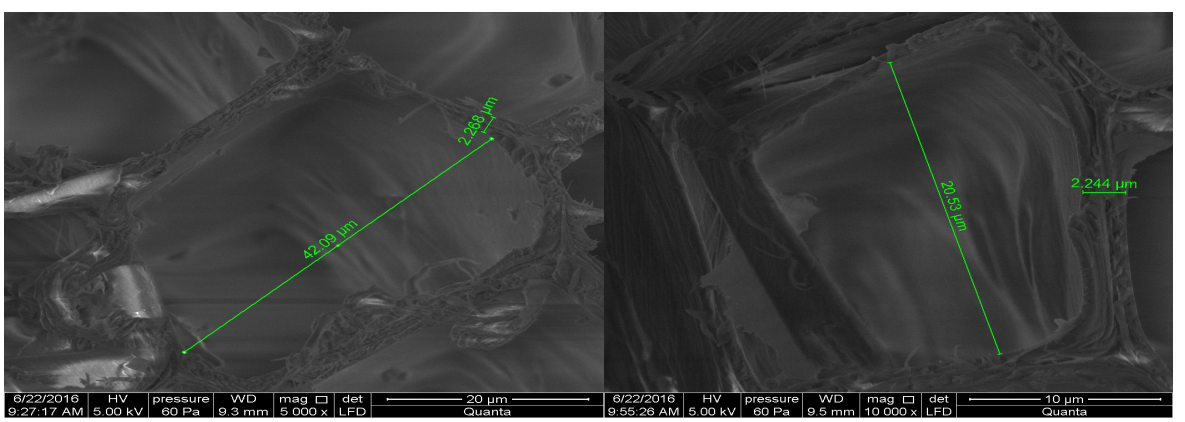

Rys. 5. Budowa mikroskopowa jodły pospolitej Abies alba Mill

Fig. 5. Microscopic structure of silver fir Abies alba Mill

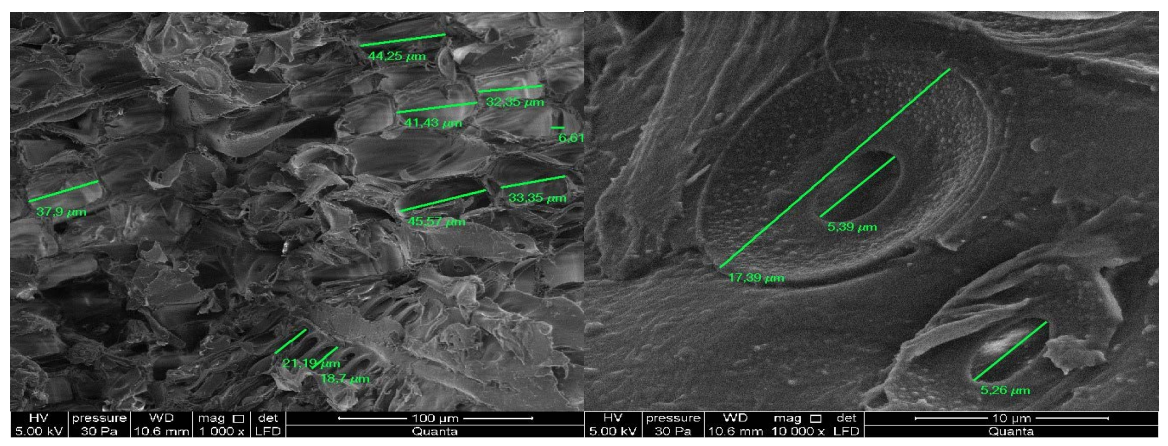

Rys. 6. Budowa mikroskopowa modrzewia europejskiego Larix decidua Mill. pochodzącego z zabytkowego obiektu wybudowanego w $1860 \mathrm{r}$.

Fig. 6. Microscopic structure of European larch Larix decidua Mill. The sample originates from a historical building constructed in 1860

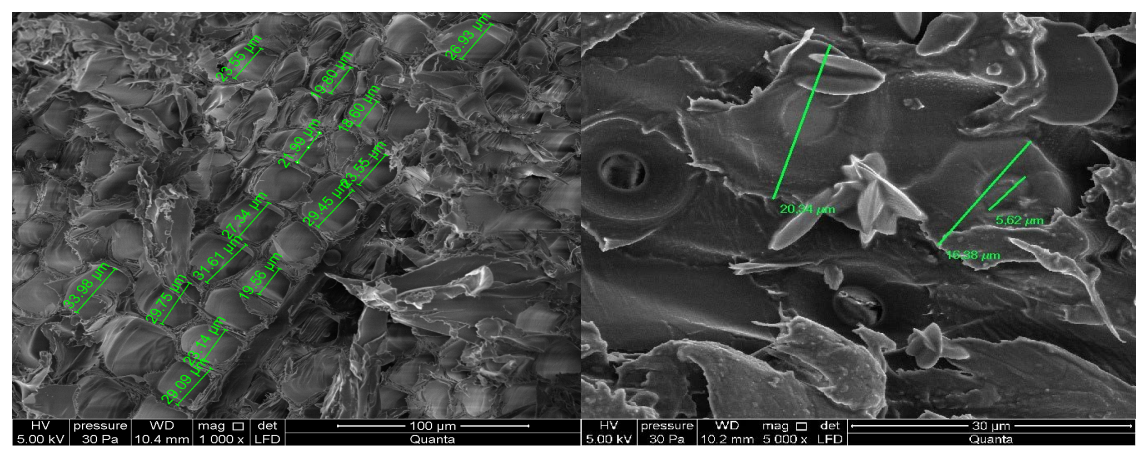

Rys. 7. Budowa mikroskopowa sosny zwyczajnej Pinus sylvestris L. poddanej 5 - letnim wpływom atmosferycznym

Fig. 7. Microscopic structure of pine Pinus sylvestris L. exposed to atmospheric conditions for five years 


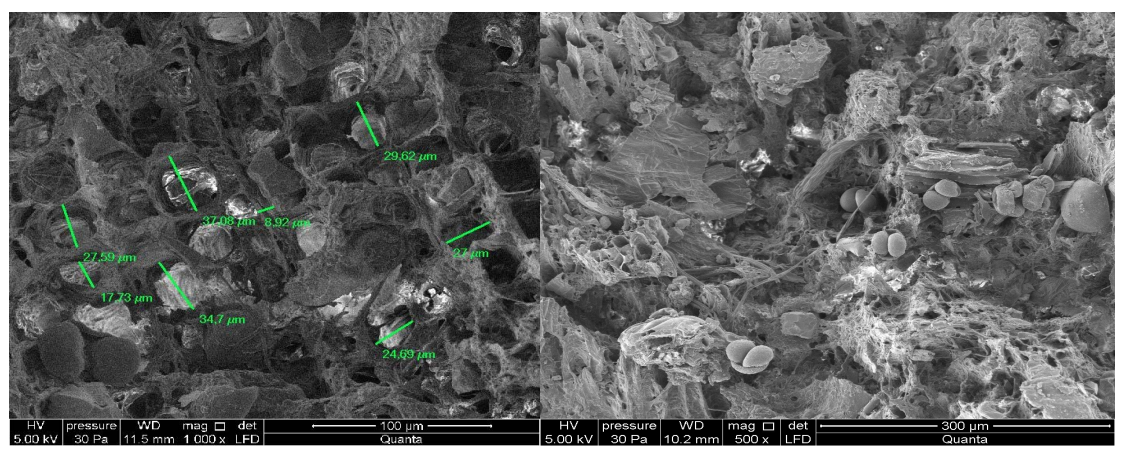

Rys. 8. Budowa mikroskopowa sosny zwyczajnej Pinus sylvestris L. - degradacja biologiczna

Fig. 8. Microscopic structure of pine Pinus sylvestris L. - biological degradation

Polepszenie funkcji wzmacniania kosztem zdolności przewodzenia, podwyższał grubość ścian a obniżał liczbę i rozmiar jamek. Doprowadziło to do zaczątku elementów o jamkach szczelinowych lub skośnych. Powiększanie się ścian i minimalizowanie jamek, spowodowało powstanie włókien. Drewno liściaste zawiera oprócz promieni rdzeniowych i miękiszu drzewnego, naczynia i włókna drzewne. Czasem naczynia o stosunkowo dużej średnicy, formują pasma zwarte, układające się od korzeni do końcowych rozgałęzień pędów. W słoju rocznym, w zależności od ułożenia naczyń, wyodrębnia się strukturę pierścieniowonaczyniową, rozpierzchłonaczyniową a także półpierścieniowonaczyniową. Naczynia o dużym świetle, u gatunków drewna pierścieniowonaczyniowego (m.in. dąb, jesion, wiąz, grochodrzew, morwa, teak, przeorzech), klasyfikują się tylko w drewnie wczesnym. Generują zwarty pierścień na przekroju poprzecznym. Drewno późne ukształtowane jest głównie z cewek włóknistych i włókien drzewnych. U gatunków takich jak klon, brzoza, grab, topola, lipa, olcha oraz większość egzotycznych, naczynia podobne średnicowo, rozprowadzone są w całym przyroście rocznym. W kraju, naczynia mają niewielką średnicę, tj. poniżej $0,1 \mathrm{~mm}$ i nie są widoczne gołym okiem. Gatunki egzotyczne mają duże naczynia, dobrze widoczne na wszystkich przekrojach drewna, a przyrosty roczne wielokroć nie są rozróżnialne. Przykładowo czereśnia, wiśnia, śliwa jako gatunki półpierścieniowo naczyniowe, charakteryzują się większą średnicą naczyń i mają ich więcej w drewnie wczesnym niż w drewnie późnym. W budowie mikroskopowej bardzo widoczna jest anizotropia drewna. Komórki w znacznej części, rozmieszczone są równolegle do osi podłużnej pnia, niektóre natomiast mają kształt bardzo wydłużonych wrzecion. Stosunek długości komórki drzewnej do jej wymiaru przekroju poprzecznego, przekracza niejednokrotnie liczbę stosunkową 100. Zatem drewno ma odmienne właściwości w różnych kierunkach anatomicznych, jest anizotropowe [1-2]. Charakterystyczne wielkości komórek obejmuje tabela 1. 
Tabela 1. Wielkości komórek strukturalnych drewna (opracowanie własne na podstawie [3])

Table 1. Sizes of timber cells (table compiled by the author on the basis of [3])

\begin{tabular}{|c|c|c|c|}
\hline L.p. & OKREŚLENIE & DLUGOŚĆ $[\mathbf{m m}]$ & ŚREDNICA [mm] \\
\hline $\mathbf{1 .}$ & CEWKI & $1-10$ & $0,02-0,04$ \\
\hline $\mathbf{2 .}$ & WŁÓKNA & $0,7-1,9$ & $0,01-0,05$ \\
\hline $\mathbf{3 .}$ & NACZYNIA & 100 i więcej & $\begin{array}{c}0,1-0,6-\text { drewno wczesne } \\
0,03-0,09-\text { drewno późne }\end{array}$ \\
\hline
\end{tabular}

\subsection{Struktura makroskopowa drewna}

Drewno to surowiec o pochodzeniu organicznym. Cechy i właściwości odzwierciedlają funkcje, które pełnią w żywym organizmie roślinnym. Wyodrębnia się trzy zasadnicze formy budowy strukturalnej: drewno iglaste, drewno liściaste rozpierzchłonaczyniowe, drewno liściaste pierścieniowonaczyniowe [3].

Cechy makroskopowe drewna są rozróżnialne nieuzbrojonym okiem, o wielkości ponad $0,1 \mathrm{~mm}$. Są to przyrosty roczne, strefy drewna późnego i wczesnego, obecność twardzieli, błyszczu, dużych naczyń, wycieków żywicznych, lub rozmieszczenie i kształt sęków itd. Cechy te, najczęściej bada się na trzech podstawowych przekrojach drewna (dwóch wzdłużnych: stycznym i promieniowym oraz jednym poprzecznym). Nie należy mieszać przekrojów anatomicznych $\mathrm{z}$ trzema kierunkami anatomicznymi: stycznym, promieniowym i wzdłuż włókien [1, 6, 9-10].

Corocznie drzewo produkuje warstwę drewna zauważalną na przekroju poprzecznym pnia w kształcie pierścienia (słój roczny) [3]. Przyrost drzew na wysokość, utrzymuje się do wieku określonego dla danego gatunku. Aczkolwiek przyrost grubości pnia dochowuje się tak długo, jak długo żyje drzewo. Biorąc pod uwagę szybkość wzrostu drzewa, wyróżnia się trzy grupy: szybko, średnio i wolno rosnące. Szybko rosnące drzewa charakteryzują się szerokimi przyrostami rocznymi, w szczególności w młodym wieku - do kilkunastu lat. Po pewnym czasie wzrost drzewa maleje, słoje roczne są węższe. Grupa tych drzew żyje krótko i nie osiąga dużych rozmiarów. Natomiast drzewa średnio i wolno rosnące uzyskują istotne wysokości przy dhugotrwałym życiu [11].

\subsubsection{Przyrosty roczne}

Drewno to tkanka złożona, która występuje u roślin naczyniowych. Płaszcz kambium w pniu drzewa - wieloletniej zdrewniałej łodydze, co roku wytrąca do wewnątrz, nową warstwę drewna w postaci pierścienia (słój roczny). W przyroście rocznym rozróżnia się warstwę drewna wczesnego - drewno jaśniejsze, o mniejszej gęstości i twardości, porowate, wydzielone na wiosnę, pełniące funkcję przewodzącą oraz warstwę drewna późnego - drewno zwarte o ciemniejszym zabarwieniu, pełniące funkcję wzmacniającą. Największy udział drew- 
na wczesnego uwidaczniają słoje roczne w centralnej części pnia. Ku obwodowi drewna, wzrasta udział drewna późnego. W warunkach wysokogórskich i dalekiej północy, wąskosłoiste drewno świerka i sosny zawiera po jednej warstwie komórek. Odmienna budowa drewna wczesnego i późnego spowodowała bardzo dobrą czytelność przyrostów rocznych w drewnie iglastym jak i pierścieniowonaczyniowym. Słabo widoczne są przyrosty roczne w drewnie rozpierzchłonaczyniowym, a niewidoczne w roślinach jednoliściennych i tropikalnych [1-2]. Zróżnicowana struktura znajdująca się $\mathrm{w}$ drewnie wczesnym i późnym, opiera się na większej średnicy komórek w strefie wczesnej i znacznym spłaszczeniu i zgrubieniu ścian komórkowych w strefie późnej. U drzew iglastych, razem ze wzrostem szerokości słoju, wzrasta poziom cienkościennego drewna wczesnego, przy czym szerokość drewna późnego stosunkowo nie zmienia się. Toteż szerokosłoiste drewno jest lżejsze i o mniejszej wytrzymałości, w stosunku do drewna wąskosłoistego, gdzie stosunek procentowy drewna późnego do wczesnego jest większy. U gatunków pierścieniowonaczyniowych, zwiększenie szerokości słojów rocznych, powoduje spadek udziału naczyń drewna wczesnego i wzrost udziału włókien drewna późnego, jak również zwiększenie wytrzymałości. Drewno szerokosłoiste jest wytrzymalsze od drewna wąskosłoistego. Gatunki rozpierzchłonaczyniowe charakteryzują się brakiem rozbieżności między drewnem późnym a wczesnym. Nie ma zależności pomiędzy szerokością słoju a udziałem drewna późnego [3]. Przyrost drewna wczesnego odbywa się w okresie wiosennym. W tym okresie, najważniejszym zadaniem jest przewodzenie wody i rozpuszczenie w niej soli mineralnych. Zatem drewno wczesne składa się z cienkościennych elementów o dużym świetle. W późniejszym okresie wegetacyjnym, powstaje drewno późne, gdzie główną rolę pełni funkcja mechaniczna. Drewno późne złożone jest z grubościennych elementów, a światło naczyń i cewek jest niewielkie. Szerokość słojów może być określana za wskaźnik technicznej właściwości drewna. U drzew iglastych, wąskosłoistość jest wskaźnikiem wyższej przydatności technicznej od szerokosłoistości. Maksimum cech wytrzymałościowych jest powiązany ze średnią szerokością słojów równą $2 \mathrm{~mm}$. Drewno pierścieniowonaczyniowe o wysokiej wytrzymałości jest określone średnią szerokością słojów rocznych równą dla dębu $-3 \mathrm{~mm}$. Drewno szerokosłoiste, w przypadku jesionu, zawiera się w przedziale $6 \mathrm{~mm}$. Udział drewna późnego wyznacza się na podstawie pomiarów liniowych. Zazwyczaj szacuje się średnią szerokość słojów. Pomiary wykonuje się na przekroju poprzecznym pnia, wzdłuż średniego promienia lub na przekroju poprzecznym próbki, celem określenia różnic pomiędzy badaną cechą techniczną i udziałem drewna późnego. Krążki albo próbki należy ciąć prostopadle do osi. Powierzchnię przekroju wygładza się a następnie określa się linię pomiaru, o przebiegu prostopadłym do słojów. Według tej linii, wykonuje się nacięcia w drewnie ostrym narzędziem, tak aby nasilić wyrazistość słojów [2]. 


\subsubsection{Biel i twardziel}

Twardziel wydzielają niektóre gatunki drzew. Umiejscowione najbliżej rdzenia, najstarsze słoje roczne, przemieniają skład chemiczny. Są mechaniczne izolowane od przyobwodowych warstw drewna za pomocą zamkniętych jamek albo wcistkowanie. Twardziel ma ciemniejszą barwę w zestawieniu z pozostałym drewnem. Dlatego też bardzo łatwo jest rozróżnić twardziel od bielu. Twardziel spełnia funkcję wzmacniającą pień. Natomiast biel utwardza pień oraz przewodzi wodę i gromadzi substancję odżywcze. Wyznacza się trzy grupy drzew, w zależności od bytowania twardzieli i jej zabarwienia: drzewa o twardzieli zabarwionej (w szczególności sosna, modrzew, daglezja), drzewa o twardzieli niezabarwionej (wśród nich świerk, jodła) oraz drzewa beztwardzielowe nie wytwarzające twardzieli. Może powstać tzw. fałszywa twardziel (rys. 9), jako objaw chorobowy [1-2].

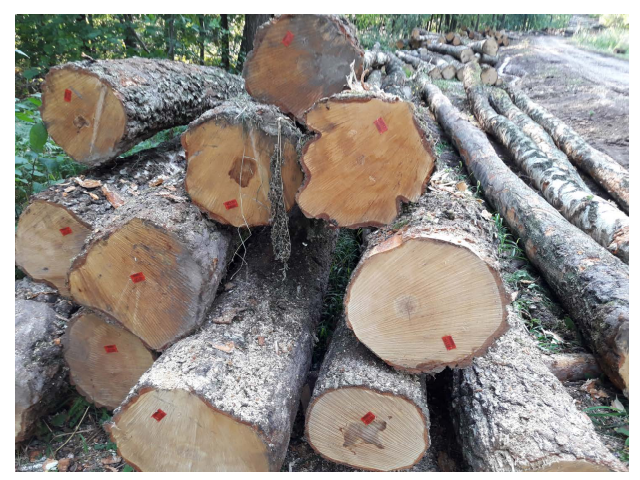

Rys. 9. Przykład fałszywej twardzieli

Fig. 9. Examples of false heartwood

\subsubsection{Pęcherze i wycieki żywiczne}

W przecięciu kanałów żywicznych dostrzegalne są wycieki żywicy, zaobserwowane u niektórych gatunków iglastych, takich jak sosna, świerk, modrzew, daglezja. Mają kształt drobnych plamek na przekroju poprzecznym a na przekrojach wzdłużnych występują w postaci kresek (smug). Zależnie od kąta padania światła lub zabrudzenia, smugi te są ciemniejsze lub jaśniejsze od otaczającego drewna. Sprawnie jest określić pęcherze żywiczne. Jeszcze za życia drzew, w rozstępach tkanki drzewnej, gromadzi się żywica. Pęcherze charakteryzują się wydłużonym kształtem, jak również ułożone są równolegle do osi pnia. Ich długość wynosi zazwyczaj kilka centymetrów. Gatunki iglaste zawierające żywicę, produkują przeżywiczenia, występujące na nadpsutych sękach. Przekrój styczny obejmuje wydłużone soczewki, ciemniejsze od otaczającego drewna [1-2]. 


\subsubsection{Promienie lykodrzewne}

Promieniami łykodrzewnymi nazywamy poziome elementy struktury drewna, prowadzące promieniowo, od rdzenia ku obwodzie pnia. Gatunki iglaste mają promienie łykodrzewne drobne i słabo widoczne, rozpoznawalne gołym okiem tylko na przekroju promieniowym. Gatunki liściaste, wśród nich dąb, buk, klon, platan, mają promienie łykodrzewne duże. Umożliwia ich określenie makroskopowo, na wszystkich trzech przekrojach. Na przekroju promieniowym tworzą błyszcz [1-2].

W odniesieniu do składu chemicznego, drewno jest niejednorodne. Ich skład jest uzależniony od gatunku drewna. W ogólności stwierdza się, że drewno ma około $50 \%$ celulozy, $20 \%$ hemiceluloz, $25 \%$ ligniny, $5 \%$ pozostałych składników [3].

\section{Przegląd typowych gatunków i rodzajów drewna iglastego}

W Polsce praktycznie tarcica konstrukcyjna jest wydobywana tylko z drewna dwóch gatunków iglastych: sosny zwyczajnej Pinus sylvestris L. i świerka pospolitego Picea abies L. Wśród państw europejskich, jedynie Niemcy i kraje skandynawskie w odniesieniu z Polską, zajmują większą powierzchnię lasów iglastych. Dlatego też istotna pozycja polskiej tarcicy sosnowej i świerkowej, nie tylko na rynku krajowym ale i zagranicznym. Według normy PN-D94021:2013-10, oprócz sosny i świerka, wyróżnić można jeszcze modrzew, jodłę i daglezję jako źródło tarcicy konstrukcyjnej [12]. Z uwagi na ich niewielką ilość, mają znaczenie drugorzędne [1].

\subsection{Sosna zwyczajna Pinus sylvestris L.}

Gatunek ten generuje lite drzewostany. Jest szeroko rozprzestrzeniony w całej Europie, występujący w części północnej i północno-wschodniej. Polska pozostaje $\mathrm{w}$ zasięgu tego gatunku, prócz terenów wysokogórskich. $\mathrm{Z}$ pominięciem limby i kosodrzewiny, sosna pospolita to jeden $z$ trzech rodzimych gatunków. W Polsce można napotkać 12 innych gatunków sosen, dla przykładu sosna wejmutka, sosna czarna, sosna Banksa, sosna smołowa. Ich wymiar nie jest dość duży. Sosna pospolita (rys. 10), ma dużą przydatność dostosowania się do warunków środowiska. Mimo to, należy do gatunków mało zmiennych. Typowa sosna pospolita osiąga do 30-40 m. W młodości, korona stożkowa z gałęziami wyrastającymi w okółkach. W późniejszym etapie rozwoju, zmienia się w formę parasolowatą. Biorąc pod uwagę drzewostany w Polsce, sosna zajmuje pierwsze miejsce. Ma największy zasięg wśród wszystkich roślin uprawianych w rolnictwie, ogrodnictwie, leśnictwie. W żadnym kraju, jak w Polsce, jeden gatunek nie zajmuje procentowo tak czołowego położenia w składzie gatunkowym lasów. Sosna to gatunek twardzielowy. Po wykarczowaniu drzewa lub przetarciu kłody, 
twardziel nie różni się od bielu. Po pewnym czasie, skokowo ciemnieje, przyjmując barwę brunatnoczerwonawą. Biel ma kolor żółtobiały, jest szeroki, ogarnia ponad 25 przyrostów rocznych. Sęki są w okółkach, koloru ciemniejszego od otaczającego drewna. Występują tam też przeżywiczenia. Wyraźne słoje roczne, szerokość uwarunkowana warunkami wzrostu drzewa. Drewno wczesne jest jaśniejsze od drewna późnego. W obszarze przyrostu rocznego, przejście z drewna wczesnego do późnego jest dość ostre. Tarcica charakteryzuje się żywicznym zapachem, co jest spowodowane licznymi wyciekami żywicznymi drzewa. Promienie łykodrzewne drobne, mało wyraźne, tylko na idealnie promieniowym przekroju. Podstawowymi wadami drewna są sinizny i przeżywiczenia. Drewno jest lekkie, miękkie i łatwo łupliwe $[1,11]$.

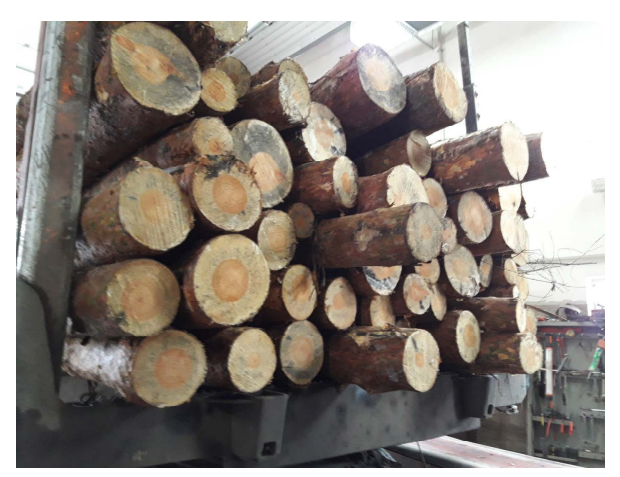

Rys. 10. Sosna zwyczajna Pinus sylvestris L. pochodząca z Nadleśnictwa Przedbórz

Fig. 10. Pine Pinus sylvestris L. from Przedbórz Forest Inspectorate

\section{2. Świerk pospolity Picea abies Karst.}

To wyłączny rodzimy gatunek świerka i jeden z siedmiu rodzimych gatunków. Formuje lite drzewostany na dużych obszarach. Zakres świerka pospolitego obejmuje obszary: alpejsko-bałkański, sudecko-karpacki, bałtycko-północnorosyjski. Dwa pierwsze obszary stanowi drzewo wysokogórskie, natomiast trzeci - nizinny. Przez Polskę ciągnie się pas bezświerkowy, rozdzielający świerk górski - świerk z obszaru sudecko-karpackiego, od świerka nizinnego - obszar bałtycko-północno-rosyjski. Różnorodne warunki, duży rozmiar, doprowadziły do powstania licznych odmian, ekotypów, form świerka. Szczegółowo nie są one nakreślone, na skutek zjawisku krzyżowego zapylenia drzew. Dlatego trudno natrafić na indywiduum, typowe do porównań. Powszechny świerk pospolity ma prosty pień, o wysokości do $50 \mathrm{~m}$. Korona jest stożkowata, gałęzie odrastają w okółkach. U młodych gatunków wykształcają się pod kątem ostrym do pobocznicy pnia i brną ku górze, natomiast u starszych poziomo. W piętrze regla górnego, gatunki te formują górskie bory świerkowe. Na obszarach nizinnych 
stanowią zespoły leśne. Pojawiają się też inne, rzadkie formy pokrojowe świerka, m.in. forma szczudłowa, sztandarowa, kolumnowa, krzaczasta. Prócz świerka pospolitego, w Europie można spotkać jeszcze trzy gatunki: świerk syberyjski Picea obovata, świerk kaukaski Picea orientalia Link., świerk serbski Picea omorica Purk. Biorąc pod uwagę obszar drzewostanów, świerk lokuje się w Polsce na drugim miejscu. Świerk ma twardziel niezabarwioną. W wyniku przetarcia, twardziel jest dostrzegalna poprzez różnicę wilgotności. Biel wilgotny jest ciemniejszy. Po wysuszeniu, różnica barwna zanika. Biel jest dostatecznie szeroka. Drewno świerka koloru białego, niekiedy jasnożółtego i lekko błyszczącego. Rozmieszczone sęki są w równomiernych okółkach, twardsze i ciemniejsze od otaczającego drewna. Podczas suszenia, nieraz obluzowują się i wypadają. Od razu, po przetarciu lub przestruganiu, występuje lekki żywiczny zapach na wyciekach żywicznych. Wyraziste słoje roczne. Drewno wczesne, szerokie i jaśniejsze, rozróżnia się od ciemniejszego drewna późnego. W przyroście rocznym, przejście z drewna wczesnego do późnego jest łagodne. Promienie rdzeniowe mało zauważalne na przekroju promieniowym. Standardowymi wadami drewna świerkowego są pęcherze żywiczne i twardzica. Drewno lekkie, miękkie, latwo łupliwe $[1,11]$.

\subsection{Modrzew europejski Larix decidua Mill.}

Drzewo iglaste o opadających igłach na zimę i wysokości do $40 \mathrm{~m}$. Ma smukłą i stożkową koronę, która zmienia się w szeroką, ze spłaszczonym wierzchołkiem. Rosnące gałęzie są niesymetryczne, pod kątem prostym do osi pnia. W pierwszym okresie, modrzew znajdował się tylko w Alpach, we wschodnich Sudetach, w Tatrach i na Niżu Polskim. W wyniku upraw leśnych, aktualnie jest rozprzestrzeniony $\mathrm{w}$ całej Europie. Posiada małe wymagania pokarmowe, co umożliwia jego wzrost na wielu siedliskach. Gatunek twardzielowy. Biel wąska, zółtawa, odróżnia się od twardzieli barwy bladobrązowej lub czerwonobrązowej. Sęki ciemnobrunatne, rozstawione niejednolicie. Widnieją sporadyczne wycieki żywiczne o nikłym żywicznym zapachu. Czytelne słoje, na skutek różnicy w zwięzłości i barwie drewna wczesnego oraz późnego. Przejście jasnego drewna wczesnego w drewno późne jest dość szorstkie. Słabo przejrzyste promienie rdzeniowe na przekroju promieniowym. Wadami tego gatunku jest silna zbieżystość oraz pęcherze żywiczne. Modrzew jest twardy, łatwo łupliwy i średnio ciężki $[1,11]$.

\subsection{Jodła pospolita Abies alba Mill.}

Pojawiają się w górach środkowej i południowej Europy, w lasach regla górnego. Jodła charakteryzuję się prostym pniem i wysokością do $50 \mathrm{~m}$. Pierwotnie stożkowa korona, przeradza się w kolumnę ze spłaszczonym wierzchołkiem. Niesystematyczne gałęzie są zwrócone ukośnie ku górze. Gatunek twardzieli niezabarwionej. Drewno koloru białego, okresami z odcieniem różowym 
lub żółtym. Tożsame z drewnem świerkowym lecz bardziej matowe. $\mathrm{W}$ drewnie jodły nie istnieją wycieki żywiczne i pęcherze. Nierównomierne sęki są jasne. Tarcica świeża ma zapach podobny do zjełczałego masła, potem jest bezwonna. Dodatnio zauważalne słoje roczne. Przejście drewna wczesnego w późne jest łagodne. Promienie łykodrzewne widoczne są tylko na idealnie promieniowym przekroju. Charakterystyczne wady to twardzica i pęknięcia okrężne. Jodła jest lekka, miękka i bardzo łatwo łupliwa $[1,11]$.

\subsection{Daglezja zielona Pseudotsuga menziesii Franco.}

Gatunek północnoamerykański. Daglezja początkowo występowała w zachodniej części Ameryki Północnej. W wieku XVIII ściągnięto ją do Europy. W kraju zasadzono ją w okresie międzywojennym, co spowodowało powstanie drzewostanów w wieku rębnym. Wiecznie zielone drzewo iglaste, osiągające nawet $100 \mathrm{~m}$ a w Europie do $50 \mathrm{~m}$. Najpierw stożkowata korona, następnie spłaszczona przez poziomo odstające konary. Gałęzie rosną w okółkach, poziomo do osi pnia. Gatunek twardzielowy. Biel jest szeroka i żółtawobiała. Tymczasem twardziel jasnożółtobrązowa, niekiedy z zielonkawym odcieniem. Gatunek drewna szerokosłoistego o znacznym udziale drewna późnego. Wyraziste słoje roczne. Bardzo ostre przejście od drewna późnego do wczesnego. Występują niewielkie i liczne wycieki żywiczne w postaci drobnych kropek na przekroju poprzecznym i kresek na przekroju wzdłużnym. Małe promienie rdzeniowe, dostrzegalne tylko na przekroju promieniowym. Sęki są ciemniejsze od otaczającego drewna. Podstawowymi wadami są pęcherze żywiczne oraz pęknięcia rdzeniowe. Drewno daglezji jest lekkie, całkiem twarde, łatwo łupliwe $[1,11]$.

\section{Makroskopowe oznaczenie drewna iglastego}

Przy diagnozowaniu drewna poszczególnych rodzajów i gatunków, powinno się brać wiele cech składających się na jego rysunek oraz związanych z jego właściwościami fizyko-chemicznymi. Przede wszystkim pozostaje wskazać typ struktury drewna: iglaste, liściaste pierścieniowonaczyniowe, liściaste rozpierzchłonaczyniowe ze strefy umiarkowanej lub tropikalnej (drewno egzotyczne) [1, 11].

Cechy odróżniające drewno iglaste od pozostałych typów drewna:

- brak naczyń, czyli niewidzialne są znikome otwory na przekroju poprzecznym oraz nieobecne drobne rowki na przekrojach wzdłużnych, identycznie jak u drewna liściastego pierścieniowonaczyniowego lub rozpierzchłonaczyniowego ze strefy tropikalnej;

- wydatnie dostrzegalne zarysowane przyrosty roczne (słoje), w drewnie liściastym rozpierzchłonaczyniowym są niemalże niezauważalne.

Po określeniu typu drewna iglastego, wyznacza się rodzaj drewna. W tabeli 2 scharakteryzowano cechy wyróżniające sosnę, świerk, modrzew, jodłę, daglezję. Do tych cech należy m.in.: zabarwienie twardzieli, szerokość bielu, wycieki 
Tabela 2. Podstawowe właściwości badawcze rodzajów drewna iglastego (opracowanie własne na podstawie [1])

Table 2. Basic distinctive properties of selected coniferous wood species (table compiled by the author on the basis of [1])

\begin{tabular}{|c|c|c|c|c|c|c|c|}
\hline Lp. & $\begin{array}{l}\text { Rodzaj } \\
\text { drewna } \\
\text { iglastego }\end{array}$ & $\begin{array}{l}\text { Zabarwienie } \\
\text { twardzieli }\end{array}$ & $\begin{array}{l}\text { Szerokość } \\
\text { przyrostów } \\
\text { rocznych }\end{array}$ & $\begin{array}{l}\text { Udzial bielu } \\
\text { i twardzieli }\end{array}$ & $\begin{array}{c}\text { Obecność } \\
\text { przewodów } \\
\text { żywicznych }\end{array}$ & \begin{tabular}{|c|} 
Przejście \\
z drewna \\
wczesnego \\
do późnego \\
\end{tabular} & $\begin{array}{l}\text { Występowanie } \\
\text { i przekrój sęka }\end{array}$ \\
\hline 1. & $\begin{array}{l}\text { ŚWIERK } \\
\text { Picea sp. }\end{array}$ & niezabarwiona & różna & - & $\begin{array}{l}\text { śladowe, } \\
\text { ledwo zau- } \\
\text { ważalne }\end{array}$ & delikatne & $\begin{array}{c}\text { w okółkach, } \\
\text { przekrój okrągły } \\
\text { na przekroju } \\
\text { stycznym }\end{array}$ \\
\hline 2. & $\begin{array}{c}\text { JODLA } \\
\text { Abies sp. }\end{array}$ & niezabarwiona & różna & - & brak & delikatne & $\begin{array}{c}\text { głównie niesy- } \\
\text { metryczne, rzut } \\
\text { zwykle eliptycz- } \\
\text { ny na przekroju } \\
\text { stycznym }\end{array}$ \\
\hline 3. & $\begin{array}{l}\text { DAGLEZJ } \\
\text { A Pseudot- } \\
\text { suga sp. }\end{array}$ & $\begin{array}{c}\text { intensywność } \\
\text { niska }\end{array}$ & $\begin{array}{l}\text { szerokosłoista } \\
(4 \mathrm{~mm})\end{array}$ & $\begin{array}{c}\text { szerokobielaste } \\
(1 / 5)\end{array}$ & $\begin{array}{l}\text { znikome, } \\
\text { nikle do- } \\
\text { strzegalne }\end{array}$ & $\begin{array}{l}\text { zbyt szorst- } \\
\text { kie, duża } \\
\text { część drew- } \\
\text { na późnego }\end{array}$ & $\begin{array}{c}\text { w okółkach, plan } \\
\text { zwykle okrągły } \\
\text { na przekroju } \\
\text { stycznym }\end{array}$ \\
\hline 4. & $\begin{array}{c}\text { SOSNA } \\
\text { Pinus sp. }\end{array}$ & $\begin{array}{l}\text { intensywność } \\
\text { średnia }\end{array}$ & różna & $\begin{array}{l}\text { szerokobielaste } \\
(1 / 3)\end{array}$ & $\begin{array}{l}\text { drobne, } \\
\text { niekiedy } \\
\text { liczne }\end{array}$ & $\begin{array}{l}\text { zbyt szorst- } \\
\text { kie }\end{array}$ & \begin{tabular}{|c|} 
w okółkach, \\
kształt eliptycz- \\
ny na przekroju \\
stycznym \\
\end{tabular} \\
\hline 5. & $\begin{array}{l}\text { MODRZE } \\
\text { W Larix sp. }\end{array}$ & $\begin{array}{c}\text { intensywność } \\
\text { wysoka }\end{array}$ & różna & $\begin{array}{c}\text { wąskobielaste } \\
(1 / 10)\end{array}$ & $\begin{array}{c}\text { nieznaczne, } \\
\text { nieraz wielo- } \\
\text { krotne } \mathrm{i} \\
\text { dobrze wi- } \\
\text { dzialne }\end{array}$ & $\begin{array}{l}\text { zbyt szorst- } \\
\text { kie }\end{array}$ & $\begin{array}{c}\text { nieregularne, } \\
\text { układ okrągły na } \\
\text { przekroju stycz- } \\
\text { nym }\end{array}$ \\
\hline
\end{tabular}

żywiczne, szerokość przyrostów rocznych, udział drewna późnego, występowanie i układ sęków. Do zdiagnozowania makroskopowego drewna mogą pomóc jego właściwości techniczne. Przeważnie te, które możemy wyznaczyć bez użycia aparatury specjalistycznej (gęstość czy twardość) $[1,11]$.

\section{Makroskopowa analiza rozpoznawcza drewna iglastego:}

- jodła - drewno białe, odcień brązoworóżowy, przejrzyste słoje roczne - wąskie w strefie przyrdzeniowej, delikatne przejście z drewna wczesnego do późnego, niesymetryczne sęki, drewno nieciężkie, brak przewodów żywicznych, niezabarwiona twardziel;

- świerk - żółtawobiałe, słoje roczne z wąską strefą drewna późnego, delikatne przejście z drewna wczesnego do późnego, sęki występujące w okółkach i lekko ciemniejsze od otaczającego drewna, twardziel niezabarwiona, w drewnie późnym - przewody żywiczne jasne, rzadkie punkty, wielokrotne pęcherze żywiczne;

- modrzew - ciemnoczerwonobrązowa twardziel, zóltawa i wąska biel, ciemne drewno późne, nagłe przejście od drewna wczesnego do późnego, sęki - częste, ciemnobrunatne i nieregularne, drewno średnio ciężkie, zabarwiona twardziel, w drewnie późnym - przewody żywiczne jasne, rzadkie, niewidoczne punkty; 
- daglezja - różowobrązowa twardziel, szeroka i brązowawa biel, wyraźne przejście od drewna wczesnego do późnego, sęki - liczne i regularne, drewno średnio ciężkie, zabarwiona twardziel, w drewnie późnym - przewody żywiczne jasne, rzadkie, niewidoczne punkty;

- sosna - czerwonobrązowa twardziel, zółtawobiała i szeroka biel; wyraźne przejście od drewna wczesnego do późnego, sęki - ciemniejsze i regularne, przeżywiczenia przysęczne o przekroju soczewek, drewno średnio ciężkie, twardziel zabarwiona, w drewnie późnym - przewody żywiczne jasne, częste i widoczne punkty [1].

\section{Podsumowanie}

Drzewa są okazałymi, długowiecznymi przedstawicielami roślin naczyniowych. Przeprowadzone rozważania literaturowe wyczerpująco scharakteryzowały najważniejsze informacje dotyczące struktury drewna konstrukcyjnego. W efekcie przytoczonego zestawienia, uzyskano przejrzystą analizę budowy mikroskopowej i makroskopowej drewna. Co więcej, zilustrowano budowę mikroskopową drewna konstrukcyjnego z wykorzystaniem skaningowego mikroskopu elektronowego (SEM). Rozpatrywane drewno sosny zwyczajnej Pinus sylvestris L. oraz modrzewia europejskiego Larix decidua Mill. posiada cewki o prostokątnym kształcie nakreślone na przekroju poprzecznym. Średnica promieniowa cewek drewna wczesnego sosny zwyczajnej Pinus sylvestris L., jodły pospolitej Abies alba Mill. oraz drewna zabytkowego modrzewia europejskiego Larix decidua Mill. jest około 2 razy większa od cewek drewna późnego.

\section{Literatura}

[1] Kozakiewicz P., Krzosek S.: Inżynieria materiałów drzewnych, Wydawnictwo SGGW, Warszawa 2013.

[2] Krzysik F.: Nauka o drewnie, Państwowe Wydawnictwo Naukowe, Warszawa 1975.

[3] Kozakiewicz P.: Fizyka drewna w teorii i zadaniach. Wybrane zagadnienia, Wydawnictwo SGGW, Warszawa 2003.

[4] Rudziński L.: Konstrukcje drewniane. Naprawy, wzmocnienia, przykłady obliczeń, Wydawnictwo Politechniki Świętokrzyskiej, Kielce 2010.

[5] Wdowiak A.: Analysis of bent timber beam reinforcement with the application of composite materials, Structure and Environment, vol. 8 (1), 2016, pp. 10-16.

[6] Wdowiak A.: Assessment of technical condition of wooden structures, Proceedings of TRANSCOM 2015, SECTION 7- CIVIL ENGINEERING, pp. 326-332.

[7] Krzosek S.: Wytrzymałościowe sortowanie polskiej sosnowej tarcicy konstrukcyjnej różnymi metodami, Rozprawy Naukowe i Monografie, Wydawnictwo SGGW, Warszawa 2009.

[8] Wdowiak A: Using the visual method to sort polish pine structural sawn timber with respect to strength, Czasopismo Techniczne 2-B/2016, pp. 219-224. 
[9] Wdowiak A., Kroner A.: Wpływ niejednorodności struktury zginanych belek z drewna klejonego na efekt ich wzmocnienia, Materiały Budowlane 1/2017, s. 87-89.

[10] Rudziński L., Wdowiak A.: Strength and structural properties of structural timber, Structure and Environment, vol. 8 (2), 2016, pp. 103-108.

[11] Kokociński W.: Anatomia drewna, Poznań 2005.

[12] PN-D-94021:2013-10 Tarcica konstrukcyjna iglasta sortowana metodami wytrzymałościowymi.

\section{STRUCTURAL TIMBER CHARACTERISTICS}

\section{S u m m a r y}

Wood is a basic raw material for paper and pulp industry, and also in power generation. Wood supplies are provided by forests. In Poland, the area of forests continues to increase annually. Since 1945 , forest cover has grown by $8.4 \%$. The increment results from afforestation of the land with former agricultural use, and of uncultivated land [1].

In the monograph, the micro- and macroscopic structure of wood from pine Pinus sylvestris L. was presented. The wood originated from four selected nature-forest areas of Poland, namely Area A - Mazowiecko - Podlaska Nature-Forest Area (Garwolin Forest Inspectorate), Area B - Małopolska Nature-Forest Area (Przedbórz Forest Inspectorate), Area C - Śląska Nature-Forest Area (Kędzierzyn Koźle Forest Inspectorate), Area D - Karpacka Nature-Forest Area (Piwniczna Forest Inspectorate). Wood microscopic structure analysis was performed for the following conifer species: silver fir Abies alba Mill, European larch Larix decidua Mill., the wood of which was obtained from a historical structure built in 1860, and pine Pinus sylvestris L., the wood of which was exposed to atmospheric conditions and biological degradation for a 5 - year period.

The following features were specified: annual rings, sapwood and heartwood, resin pockets and leaks, and also medullary rays. The distinctive properties of selected coniferous wood species were presented, including heartwood colour, the width of annual rings, sapwood and heartwood content, the occurrence of resin ducts, transition from earlywood to latewood, and also knot structure.

Additionally, the characteristics of the wood of the following species were provided: pine Pinus sylvestris L., spruce Picea abies Karst., European larch Larix decidua Mill., silver fir Abies alba Mill., Douglas fir Pseudotsuga menziesii Franco [1-2].

Keywords: wood, microscopic structure, macroscopic structure, annual rings, sapwood and heartwood, resin pockets and leaks, medullary rays, pine Pinus sylvestris L., spruce Picea abies Karst., European larch Larix decidua Mill., silver fir Abies alba Mill., Douglas fir Pseudotsuga menziesii Franco

Przestano do redakcji: 06.03.2017 $r$.

Przyjęto do druku: 15.12.2017 r. 